\title{
Evaluation of Trace Elements in the Nails and Hair of Farmers Exposed to Pesticides and Fertilizers
}

\author{
Zariyantey Abdul Hamid ${ }^{1}$, Ismarulyusda Ishak ${ }^{1}$, Syarif Husin Lubis ${ }^{1}$, Nihayah Mohammad ${ }^{1}$, \\ Hidayatulfathi Othman ${ }^{1}$, Nur Zakiah Mohd Saat ${ }^{1}$, Ahmad Rohi Ghazali ${ }^{1}$, Siti Zakiah Abdul Rahim ${ }^{1}$ \\ \& Mohamad Roff Mohd Noor ${ }^{2}$ \\ ${ }^{1}$ Programme of Biomedical Science, School of Diagnostic and Applied Health Sciences, Faculty of Health \\ Sciences, Universiti Kebangsaan Malaysia, Kuala Lumpur, Malaysia \\ ${ }^{2}$ Malaysian Agricultural Researh and Development Institute (MARDI), Serdang, Selangor, Malaysia \\ Correspondence: Ismarulyusda Ishak, Programme of Biomedical Science, School of Diagnostic and Applied \\ Health Sciences, Faculty of Health Sciences, Universiti Kebangsaan Malaysia, 50300 Jalan Raja Muda Abdul \\ Aziz, Kuala Lumpur, Malaysia. Tel: 60-392-897-615. E-mail: ismarul@ukm.edu.my
}

Received: October 3, 2017

Accepted: December 20, 2017

Online Published: December 31, 2017

doi:10.5539/jas.v9n13p79

URL: https://doi.org/10.5539/jas.v9n13p79

\begin{abstract}
Exposure to pesticides and fertilizers lowers the level of trace elements in the human body for several reasons. This study aimed to investigate the effect of pesticide exposure to the levels of trace elements of farmers in Bachok and Tumpat, Kelantan, Malaysia. This cross sectional study involved 89 farmers. Demographic data and information on the duration of the exposure to the pesticides and fertilizers, as well as personal protective equipment (PPE) practice habits, were determined through questionnaire. The levels of selenium, manganese, zinc, copper and chromium samples of fingernails, toenails and hair were determined through the use of inductively coupled plasma-mass spectrometry (ICP-MS). The levels of the trace elements were not influenced by gender, age and the period of exposure. Only the manganese levels found in the hair samples $(r=0.250)$ show a significant positive correlation $(\mathrm{p}<0.05)$ with the working period. PPE practice habit also have significant correlation $(\mathrm{p}<0.05)$ with manganese level in fingernails $(\mathrm{r}=0.530)$ and toenails $(\mathrm{r}=-0.353)$, zinc level in hair $(r=-0.439)$ and chromium level in fingernails $(r=-0.306)$. Exposure towards pesticide and fertilizer decreased the trace element level in nails and hair of farmers. Additionally, the level of trace elements can be influenced by health status, working period, dietary habit and PPE practices.
\end{abstract}

Keywords: farmers, fertilizer, hair, nails, nutrition, personal protective equipment (PPE), pesticide exposure, trace element

\section{Introduction}

Trace elements are essential components of human biological structures. They are involved in most of the biochemical processes in the human body. Exposure to pesticides and fertilizers has been shown lower the levels of trace elements in the human body as an antagonistic effect from the heavy metals that pesticides and fertilizers contain (Watts, 1990). However, a deficiency of these elements can disturb some metabolic processes in the body, which eventually leads to various health problems. The five trace elements that were assessed in this study are selenium $(\mathrm{Se})$, manganese $(\mathrm{Mn})$; zinc $(\mathrm{Zn})$, copper $(\mathrm{Cu})$ and chromium $(\mathrm{Cr})$.

Selenium is best known as an antioxidant and a catalyst for the production of active thyroid hormone. Selenium is necessary for the proper functioning of the immune system and is important in counteracting the development of virulence and inhibiting the progression of HIV to AIDS. A deficiency in selenium can lead to various health problems such as a loss of immunocompetence (Rayman, 2000).

Manganese is necessary for normal immune function and the regulation of blood sugar. A manganese deficiency leads to growth impairments, impaired reproductive functions and impaired glucose tolerance as well as alterations in lipid and carbohydrate metabolism (Griffith, 2000).

Zinc has multiple relevant functions in biological systems such as structural function in a large number of proteins. A deficiency of zinc will disrupt the integrity of blood vessels (Bergomi et al., 1997) and also affects the 
immune system, wound healing mechanisms and the DNA synthesis process (Hamilton, Gilmore, \& Strain, 2000).

In humans, copper is necessary for the development of connective tissue, nerve coverings and bone. Copper acts as a reducing agent for a number of essential enzymes, such as superoxide dismutase (CuSOD), cytochrome oxidase and several other oxidases that reduce molecular oxygen (Watts, 1989).

Chromium potentiates the action of insulin in carbohydrate, lipid and protein metabolism. The best known function of chromium is its role as a regulator of insulin action. The clinical manifestations of a chromium deficiency includes impaired glucose tolerance, hyperglycemia, relative insulin resistance and peripheral or central neuropathy (Mann \& Truswell, 2002).

Exposure to pesticides and fertilizers lowers the level of trace elements in the human body for several reasons. Up to our knowledge, reports concerning the impact of pesticide exposure on trace elements among farmers in Malaysia remain underreported. Thus, the needs to carry out epidemiological studies to address pesticide toxicity in occupationally exposed farmers in Malaysia are crucial. With that, this study is aimed to determine the status of trace elements among Malaysian farmers with record of pesticide exposure focusing on farmers from Tumpat and Bachok, Kelantan. Together, outcome from this study can generate further information regarding the safety aspect of farming activities in Malaysia for a sustainable and safer agriculture sectors.

\section{Methods}

\subsection{Subjects and Sampling}

This cross-sectional study from 2013 to 2014 involved 83 farmers between the ages of 18 to 60 that were selected using a cluster sampling method from Lembaga Kenaf dan Tembakau, Bachok and Pertubuhan Peladang Kawasan, Tumpat, Kelantan, Malaysia. The design of this research study was approved by the UKM Research Ethics Committee (UKM 1.5.3.5/244/NN-201-2010). The subjects were interviewed to obtain the sociodemographic data, dietary intake data and smoking habits by using a validated questionnaire. Their health status was determined by examining the blood pressures and blood glucose levels.

The hair and nail sample were collected from the farmers who used pesticides and fertilizers for more than one year and who had previously fill out the questionnaire for the trace elements analysis. The hair samples were collected from different areas near the scalp using stainless steel scissors. The samples were then stored in zip-lock plastic bags that were properly labeled (Rodrigues, Batista, Nunes, Passos, \& Barbosa, 2008). The amount of hair taken for the analysis varied between $0.0020 \mathrm{~g}$ and $0.0030 \mathrm{~g}$ per subject. Nails were collected from all ten fingers and toes using nail clippers and were stored separately in zip-lock plastic bags. All the apparatuses and glassware for the trace elements analyses were specially cleaned by soaking them in a $5 \%$ nitric acid solution for 24 hours; subsequently rinsed with deionized water with a resistivity of $18.0 \mathrm{M} \Omega$ (Thermo Scientific, UK) and then dried in an oven.

\subsection{Washing}

Different washing procedures for the removal of exogenous contamination containing trace elements have been proposed. In this research study, the hair and nails samples were washed by using the method proposed by the IAEA, with some modifications (Ryabukhin, 1978). The hair samples were weighed and cut into approximately $1 \mathrm{~cm}$ sections before being soaked in separate solution of $10 \mathrm{ml}$ of $0.5 \%$ Triton-X, $10 \mathrm{ml}$ of deionized water and $8 \mathrm{ml}$ of acetone (E. Merck, Germany) for 10 minutes each at room temperature. Next, the hair samples were rinsed 3 times with deionized water and finally washed again with acetone. The hair samples were dried in the incubator at $45{ }^{\circ} \mathrm{C}$ (Mehra \& Jenuja, 2004). The nail samples were weighed and soaked in $10 \mathrm{ml}$ of $0.5 \%$ Triton-X for 2 hours, followed by $8 \mathrm{ml}$ acetone for 1 hour (Slotnick \& Nriagu, 2006). Finally, they were rinsed with deionized water and dried overnight in the incubator at $45^{\circ} \mathrm{C}$ (Mehra \& Jenuja, 2004).

\subsection{Digestion}

In this study, the digestion process is to completely solubilize the samples. The acidic digestion method was implemented through the use of nitric acid, $\mathrm{HNO}_{3}$ in combination with peroxide, and $\mathrm{H}_{2} \mathrm{O}_{2}$ to wash the sample. The washed hair and nail samples were added to $2 \mathrm{ml}$ of $65 \% \mathrm{HNO}_{3}$ (E. Merck, Germany) and heated at 200 to $250{ }^{\circ} \mathrm{C}$ on the block digester for approximately 10 minutes before adding $0.2 \mathrm{ml}$ of $\mathrm{H}_{2} \mathrm{O}_{2}$ (Scharlau, Germany) for approximately 5 minutes, or until the bubbles stopped appearing (Rodushkin \& Axellsson, 2000). The glass marbles was placed on top of each test tube to avoid evaporation during heating. 


\subsection{Dilution}

The digested solutions were diluted by adding deionized water up to a volume of $10 \mathrm{ml}$ and gently shaking the solution to mix it. The solutions were then filtered with $11 \mathrm{~cm}$ filter paper (Whatman, England) into $15 \mathrm{ml}$ polypropylene tubes and stored at $4^{\circ} \mathrm{C}$ until they were analyzed with ICP-MS (Perkin Elmer, USA).

\subsection{Sample and Data Analysis}

The levels of selenium, manganese, zinc, copper and chromium in the hair, fingernail and toenail samples were determined by ICP-MS, and the data were analyzed statistically with PASW version 18.0. The results were considered significant with a p-value of $<0.05$. All data that were not normally distributed were presented as the in median and interquartile range ug/l only. The $\mathrm{Zn}$ and $\mathrm{Cu}$ toenail samples were normally distributed and were presented as the mean \pm standard deviation. The data that were collected included gender, age (years), age group $(<45,45-60,>60)$, smoking habits (yes, no), working duration (years), pesticide usage duration (hours per month), fertilizer usage duration (hours per month), Personal Protective Equipment (PPE) score $(<5,5-6,>6$ ), PPE used, types of plantation (vegetable, tobacco, paddy) and types of pesticides used (organophosphate, carbamate, pyrethrin, pyrethroid, tiazin). The dietary habit questionnaires (DHQ) were collected using a reliable and validated instrument (Suzana, Earland, \& Suriah, 2000) and entered into Nutritionist Pro to analyze the levels of trace elements in the diets of subjects. Health status indicators, such as systolic blood pressure and blood glucose levels, were also assessed to look the associations between systolic blood pressure and zinc, and between blood glucose and chromium.

PPE score were reviewed to determine the effects of PPE use by farmers who handle pesticides and fertilizers on the levels of trace elements in fingernails, toenails and hair. The following PPE were included in this study: a hat or head covering, long sleeves, long pants, goggles, face masks, gloves and boots. The scoring was conducted by giving one mark for the use of a certain PPE and no mark if that PPE was not used (Nordin et al., 2001). A score of less than five indicated that the farmers used four or less PPEs out of the total seven PPEs required. A score of five to six indicated that the farmer's use either five or six of the PPEs required, and a score of more than six indicated that the farmers used all seven of the PPEs required.

Independent $t$ Test or Mann Whitney test were employed for comparison between two groups and one way ANOVA or Kruskall Walis were employed for comparison between more than two groups. To determine association between factors, Pearson's or Spearman correlation were employed.

\section{Results}

A total of 83 subjects, consisting of $71.1 \%$ men and $28.9 \%$ women, participated in this study (Table 1). All of the subjects were farmers and have been categorized into three age groups: 45 years old or younger, 45 to 60 old and greater than 60 years old. The farmers worked as vegetables, tobacco and paddy farmers. Almost half of the subjects had worked as a farmer for less than 24 years and had used pesticides and fertilizers for less than 8 hours per month. Mostly, the types of pesticide used by the farmers were Pyrethrin (59.8\%) and Carbamate (58.5\%). Of all the farmers who participated in this study, $42.2 \%$ were smokers. A total of $26(31.4 \%)$ of the farmers used five to six types of PPEs while 8 (9.6\%) used all 7 types of PPEs. Table 2 shows levels of the trace elements in the fingernail, toenail and hair samples of the farmers. 
Table 1. Background of subject (farmers)

\begin{tabular}{|c|c|c|c|}
\hline Sociodemographic data & & $\mathbf{n}$ & Percentage $\%$ \\
\hline \multirow[t]{2}{*}{ Gender } & Male & 59 & 71.1 \\
\hline & Female & 24 & 28.9 \\
\hline \multirow[t]{3}{*}{ Age (year) } & $<45$ & 18 & 21.7 \\
\hline & $45-60$ & 47 & 56.6 \\
\hline & $>60$ & 18 & 21.7 \\
\hline \multirow[t]{2}{*}{ Smoking habit } & Yes & 35 & 42.2 \\
\hline & No & 48 & 57.8 \\
\hline \multirow[t]{3}{*}{ Working duration (year) } & $<24$ & 41 & 49.4 \\
\hline & $24-35$ & 23 & 27.7 \\
\hline & $>35$ & 19 & 22.9 \\
\hline \multirow[t]{3}{*}{ Pesticides usage duration (hour per month) } & $<8$ & 32 & 42.1 \\
\hline & $8-12$ & 25 & 32.9 \\
\hline & $>12$ & 19 & 25.0 \\
\hline \multirow[t]{3}{*}{ Fertilizers usage duration (hour per month) } & $<8$ & 38 & 52.1 \\
\hline & $8-12$ & 20 & 27.4 \\
\hline & $>12$ & 15 & 20.5 \\
\hline \multirow[t]{3}{*}{ PPE score } & $<5$ & 8 & 9.6 \\
\hline & $5-6$ & 26 & 31.4 \\
\hline & $>6$ & 49 & 59.0 \\
\hline \multirow[t]{8}{*}{ PPE used } & Hat/head cover & 74 & 89.2 \\
\hline & Long sleeves & 78 & 94.0 \\
\hline & Long pants & 81 & 97.6 \\
\hline & Goggle & 78 & 94.0 \\
\hline & Face mask & 74 & 89.2 \\
\hline & Fabric glove & 27 & 32.5 \\
\hline & Rubber glove & 51 & 61.4 \\
\hline & Boots & 73 & 88.0 \\
\hline \multirow[t]{3}{*}{ Types of plantation } & Vegetables & 59 & 71.0 \\
\hline & Tobacco & 42 & 50.6 \\
\hline & Paddy & 20 & 24.1 \\
\hline \multirow[t]{5}{*}{ Types of pesticides used } & Organophosphate & 4 & 4.9 \\
\hline & Carbamate & 48 & 58.5 \\
\hline & Pyrethrin & 49 & 59.8 \\
\hline & Pyrethroid & 6 & 7.3 \\
\hline & Triazin & 27 & 32.9 \\
\hline
\end{tabular}

Table 2. Level of trace elements in samples

\begin{tabular}{llll}
\hline \multirow{2}{*}{ Trace elements } & \multicolumn{3}{c}{ Median (interquartile range) $\boldsymbol{\mu g} / \mathbf{L}$} \\
\cline { 2 - 4 } & Fingernails & Toenails & Hair \\
\hline Selenium & - & - & $21007(54910)$ \\
Manganese & $58.60(58)$ & $175.91(411)$ & $41.86(98.37)$ \\
Zinc & $1258(925.520)$ & $881(387.25)$ & $462.72(558.84)$ \\
Copper & $177.26(167.59)$ & $98.57(44.52)$ & $66.94(39.89)$ \\
Chromium & $183.33(7027)$ & $3323(4320)$ & $4030(3378)$ \\
\hline
\end{tabular}

\subsection{Selenium}

The levels of selenium only found in the hair samples, and showed there were no significant differences $(\mathrm{p}=$ 0.579 ) between men and women and no dependence on age (Table 3). However, the levels of selenium in the 
hair samples were lower in the farmers who used all of the $\mathrm{PPE}_{\mathrm{s}}$, but this difference was not significant ( $\mathrm{p}=$ $0.257)$. There was a significant $(\mathrm{p}<0.05)$ negative correlation between the selenium levels in the farmer-s hair samples with the selenium levels found in their diets $(r=-0.275)$. A correlation test showed that the working duration, the pesticides and fertilizers usage duration and the PPE scores did not have a significant $(p>0.05)$ relationship with the levels of selenium in any of the samples (Table 4).

Table 3. Differences of trace elements ( $\mathrm{p}$ value) according to agricultural activities, socio-demographic factors and health status

\begin{tabular}{|c|c|c|c|c|c|c|c|c|c|c|c|c|c|}
\hline \multirow[b]{2}{*}{ Factors } & \multirow{2}{*}{$\begin{array}{l}\text { Selenium } \\
\text { Hair }\end{array}$} & \multicolumn{3}{|c|}{ Manganese } & \multicolumn{3}{|c|}{ Zinc } & \multicolumn{3}{|c|}{ Copper } & \multicolumn{3}{|c|}{ Chromium } \\
\hline & & $\begin{array}{l}\text { Finger } \\
\text { nails } \\
\end{array}$ & $\begin{array}{l}\text { Toe } \\
\text { nails } \\
\end{array}$ & Hair & $\begin{array}{l}\text { Finger } \\
\text { nails } \\
\end{array}$ & $\begin{array}{l}\text { Toe } \\
\text { nails }\end{array}$ & Hair & $\begin{array}{l}\text { Finger } \\
\text { nails }\end{array}$ & $\begin{array}{l}\text { Toe } \\
\text { nails }\end{array}$ & Hair & $\begin{array}{l}\text { Finger } \\
\text { nails }\end{array}$ & $\begin{array}{l}\text { Toe } \\
\text { nails }\end{array}$ & Hair \\
\hline \multicolumn{14}{|c|}{ Working duration (year) } \\
\hline p-value & 0.483 & 0.835 & 0.874 & 0.115 & 0.942 & 0.219 & 0.994 & 0.969 & 0.257 & 0.135 & 0.496 & 0.553 & 0.635 \\
\hline \multicolumn{14}{|c|}{ Pesticides usage duration (hour per month) } \\
\hline p-value & 0.141 & 0.531 & 0.172 & 0.230 & 0.576 & 0.984 & 0.902 & 0.611 & 0.217 & 0.894 & 0.513 & 0.702 & 0.261 \\
\hline \multicolumn{14}{|c|}{ Fertilizers usage duration (hour per month) } \\
\hline p-value & 0.858 & $\begin{array}{r}0.285 \\
-\end{array}$ & 0.857 & $\begin{array}{c}0.365 \\
-\end{array}$ & 0.622 & 0.847 & 0.747 & $<0.05^{*}$ & 0.676 & $<0.05^{*}$ & 0.985 & 0.118 & 0.742 \\
\hline \multicolumn{14}{|c|}{ PPE score } \\
\hline p-value & 0.257 & 0.363 & 0.133 & 0.124 & 0.641 & 0.275 & $<0.05^{*}$ & 0.649 & 0.890 & 0.586 & 0.520 & 0.635 & 0.185 \\
\hline \multicolumn{14}{|l|}{ Gender } \\
\hline p-value & 0.579 & 0.286 & 0.827 & 0.143 & 0.061 & 0.775 & 0.846 & 0.973 & 0.350 & 0.749 & 0.535 & 0.275 & 1.000 \\
\hline \multicolumn{14}{|l|}{ Age } \\
\hline p-value & 0.260 & 0.217 & 0.087 & 0.629 & 0.340 & 0.414 & 0.102 & 0.732 & $<0.05^{*}$ & 0.424 & 0.597 & 0.913 & 0.082 \\
\hline \multicolumn{14}{|c|}{ Smoking habit } \\
\hline p-value & 0.250 & 0.315 & 0.360 & 0.063 & 0.907 & 0.132 & 0.458 & 0.291 & 0.426 & 0.675 & 0.247 & 0.091 & 0.859 \\
\hline \multicolumn{14}{|c|}{ Systolic blood pressure ( $\mathrm{mmHg}$ ) } \\
\hline p-value & & & & & 0.093 & 0.961 & 0.149 & & & & & & \\
\hline \multicolumn{14}{|c|}{ Blood glucose $(\mathrm{mmol} / \mathrm{L})$} \\
\hline p-value & & & & & & & & & & & 0.574 & 0.103 & 0.172 \\
\hline
\end{tabular}

Note. ${ }^{*}$ shows significant difference at $\mathrm{p}<0.05$.

Table 4. Correlation coefficient (r) of between trace elements and agricultural activities, nutritional status and health status

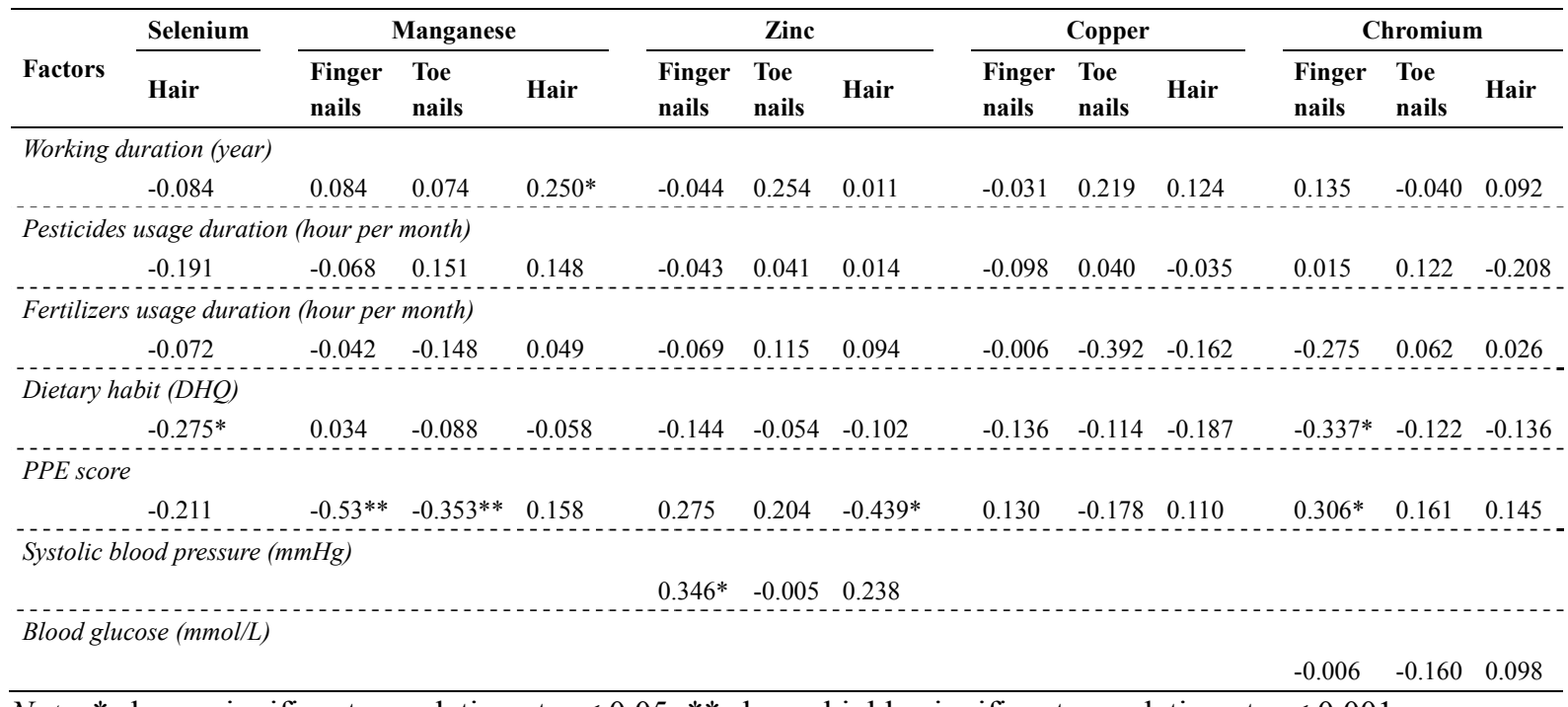

Note. ${ }^{*}$ shows significant correlation at $\mathrm{p}<0.05 ; * *$ shows highly significant correlation at $\mathrm{p}<0.001$. 


\subsection{Manganese}

There were no significant differences $(p>0.05)$ in the levels of manganese between genders and age groups (Table 3). The manganese level were lower in all the samples of smokers and the nails samples of farmers with a PPE score of less than five, but they were higher in nails samples of farmers with a PPE score of greater than six. However, these differences were not significant $(p>0.05)$. A correlation test showed that the working duration, the pesticides and fertilizers usage duration and the dietary intake were not associated with the levels of trace elements in all of the samples. However, the manganese levels in fingernails and toenails were strongly influenced by the PPE practices shown as a moderate negative correlation $(p<0.05)$ between manganese levels and PPE score (Table 4). The usage of PPE decreased manganese level.

\subsection{Zinc}

The levels of zinc were not significantly different $(\mathrm{p}>0.05)$ between genders, age groups, dietary intakes, working durations, or pesticide and fertilizer usage duration (Table 3).The levels of zinc in smokers and non-smokers were almost equal in the fingernails sample but were lower in the toenail and hair sample of smokers. The farmers with a high systolic blood pressure showed lower levels of zinc in their nails sample but higher zinc levels in their hair sample. The levels of zinc were lower in fingernail and hair samples of the farmers with a PPE score of less than five but higher in the farmers with a PPE score of greater than six. None of the differences were found to be significant $(\mathrm{p}>0.05)$. However, the zinc levels in the hair samples were moderately negatively correlated $(\mathrm{r}=-0.439, \mathrm{p}<0.05)$ with the PPE scores while the zinc levels in the fingernails sample were moderately negatively correlated with systolic blood pressure $(r=-0.346, p<0.05)$ (Table 4).

\subsection{Copper}

The levels of copper were not significantly different $(\mathrm{p}>0.05)$ when comparing between genders, age groups, working durations, pesticide usage durations and PPE scores (Table 3). However, the copper levels were significantly higher $(\mathrm{p}<0.05)$ in the toenail samples of farmers who were 60 years or older and significantly lower $(p<0.05)$ when there was an increase in fertilizer usage durations. The copper levels were lower in fingernail and hair samples but higher in toenail samples of smokers; however, there were no significant difference between those groups. There was evidence of weak correlations $(p>0.05)$ between copper levels and dietary intake, working period, pesticide and fertilizer usage period and, PPE practice (Table 4).

\subsection{Chromium}

The levels of chromium were not significantly different $(\mathrm{p}>0.05)$ between genders, age groups, working durations, pesticide and fertilizer usage durations and PPE scores (Table 3). The levels of chromium were not significantly $(\mathrm{p}>0.05)$ lower when there was an increase in working duration or, an increase in pesticide and fertilizer usage duration. The levels of chromium were not significantly $(p>0.05)$ lower in toenail or hair samples, but they were higher in the fingernail samples of smokers and farmers with a PPE score of less than five. There was also a moderate positive correlation between the levels of chromium in the fingernail samples and PPE practices $(r=0.306, p<0.05)$. A moderate negative correlation was found between the chromium levels in the fingernail samples and dietary chromium intake (DHQ) $(r=-0.337, p<0.05)$. Additionally, a very weak correlation $(p>0.05)$ between the levels of chromium and blood glucose was found (Table 4).

\section{Discussion}

This epidemiological study showed the differences in the levels of trace elements according to gender, age group and location (Ismarulyusda et al., 2009). This study was conducted to investigate the effects of occupational exposures on the level of the trace elements in the body. Farmers were chosen because of their high occupational exposure to an involvement with pesticides and fertilizers, which are known to contain various trace elements, including copper, manganese, zinc and other heavy metals that can interact with each other (Shomar, 2006). For example, increase levels of zinc can cause a decrease in the levels of copper in the human body. This occurs because both elements compete for binding at the same binding site at metallothionein (Centers for Disease Control and Prevention [CDC], 2006). Exposure can occur in many forms such as through inhalation, ingestion and dermal contact (Dosemeci et al., 2002; Nordin et al., 2001), as well as during handling (Jeyaratnam, 1990), which involve spraying, transporting or delivering, storing, processing and disposing of pesticide and fertilizer (Fleming, Gomez-Martin, Zheng, Ma, \& Lee, 2003). In these exposures, the pesticides have been found to be involved in several diseases that can eventually cause death. This study emphasizes the impact of the duration of the exposure to pesticides and fertilizers. There are also several factors that may affect the levels of trace elements in the body, such as gender, age, smoking, dietary habits, health status and PPE practice. 
The levels of trace elements were measured in three samples each individual: this method was, used to derive a more accurate picture of the exposure effects of pesticides and fertilizers because each sample contained different concentrations of the trace elements. The used of urine, blood and serum samples have been said to more accurately reflect the effects of exposure because they interact directly with the body. However, they are only suitable for short-term effects because homeostasis will correct any elemental imbalance in those substances (Longnecker et al., 1993). It is said that by using fingernail and hair samples, one is not able to distinguish between endogenous and exogenous contamination. Therefore, the toenails samples are able to provide a more accurate picture of the exposure effect because they are less exposed to any exogenous contamination. There were also no standard reference ranges of trace elements because various types of methods and instruments have been used on the different populations under study.

In this study, the selenium levels in fingernail and toenail samples were very low and could not be detected by the instrument used. This was caused by several factors such as contamination during sample (Adair, Hudgens, Schmitt, Calderon, \& Thomas, 2006) and errors that occurred while operating the instrument. It is important to ensure that aspects of cleanliness and care are considered while doing the calibration, control and preparation of the standard graph to minimize any potential error. In addition, the element itself may lack stability, especially when stored for a long period of time. Sukumar (2006) suggested that the samples are best when stored for less than five days before being processed to ensure stability of the selenium and the priority quality assurance of the measurements.

There were differences between the levels of trace elements in men and women due to their differences in metabolism, physiology, levels of knowledge and practices, awareness and the handling and use of pesticides and fertilizers. Men were more likely to make the decision of which pesticides and fertilizers were used and to do the actual spraying activity (Chojnacka, Zielinska, Michalak, \& Gorecki, 2010). However, the differences were not significant enough to say that the levels of trace elements were influenced by the gender differences.

Cigarettes are also known to be a major source of heavy metals, such as cadmium and lead (Mortada, Sobh, \& el-Defrawy, 2004). These elements will interact with trace elements in the body, thus lowering the levels of trace elements in the body (Sukumar, 2006). The interaction between toxic heavy metals and trace elements has not been understood clearly. However, previous study has reported that in occupational exposure to cadmium or lead, antioxidant potential of the body is disturbed, which is manifested by changes in both the concentration of trace elements and the activity of some enzymes (Wąsowicz, Gromadzińska, \& Rydzyński, 2001). However, study among farmers from MADA Kedah showed heavy metals (cadmium, lead and arsenic) were within normal range (Ghazali et al., 2012). In a study on the levels of selenium in toenails, it was also said that the tobaccos in cigarettes could disrupt the absorption of selenium (Ghandirian et al., 2000).

In studying the effects of trace elements on health status, two of the studied elements were zinc and chromium. Low zinc levels may increase the oxidative stress in cells:, hence this may disrupt the function of endothelial cells in blood vessels (Bergomi et al., 1997). Trivalent chromium is involved in enhancing the role of insulin activity, by helping eliminate excess insulin in the blood and assisting the cells in glucose uptake. Low levels of chromium can cause glucose intolerance syndrome, which is a similar condition to diabetes (Moukarzel, 2009). However, no differences significant relationships were found between those conditions, in contrast previous studies (Sukumar \& Subramanian, 1992). This may have occurred due to dietary factors and long-term medication that influenced the levels of zinc and chromium in the body. High levels of chromium in the hair of farmers who were hyperglycemic could also have been caused by external contamination, such as shampoo use (Jeejeebhoy, 1994). Study among farmers in Kelantan showed no significant difference of chromium levels between gender, age groups, and glucose level and diet intake (Nurfariha, 2014).

Theoretically, the levels of trace elements will decrease with an increase in the duration of exposure. However, this study showed the opposite result, which is supported by Dosemeci et al. (2002). This may have occurred due to factors such as the distance from and the dose of the exposures. Although some farmers worked long hours, the exposures may have only occurred at the workplace because houses were far from the spray area, whereas some farmers who worked for only a short period, were reside nearby to the spray area. Apart from the exposure period, the spraying techniques, handling of pesticides and fertilizers and PPE practices seemed have the greatest effect on the rate of exposure. This not only involved the practice of wearing PPEs, but it also involved the handling techniques before and after the use of PPEs (Dosemeci et al., 2002). PPEs used must be cleaned well and kept away from pesticides and fertilizers to reduce the potential for excessive exposure. Improper use of PPEs has been reported to increase the risk of exposure (Zariyantey et al., 2014). 
Nutrition information is important in order to see the relationship between dietary intake and the exposure duration on the levels of trace elements because dietary intake influenced trace element levels in human (Ismarulyusda et al., 2005). A significant relationship was only found between selenium levels in the fingernail and hair samples with dietary intake. In a study among rural subjects in Malaysia, it was shown that a low intake of selenium in the diet was most likely responsible for their selenium deficiencies because Malaysians live in remote and rural area and rarely eat selenium-enriched plants and foods such as broccoli, tuna, brown rice, oatmeal and seafood (Ismarulyusda et al., 2005). This result is supported by previous study that demonstrated that fingernails reflect the levels of selenium intake from the diet (Slotnick \& Nriagu, 2006). However in this study, dietary history information was totally dependent upon the memory of the farmers. Because most of the farmers were 45 years and older, the farmers were likely to forget and may have failed to provide accurate nutrition information. In addition, the USDA reference values are also less suitable for Malaysians because their nutritional needs are different, especially compared to the farmers in this study.

\section{Conclusion}

The two factors that act indirectly in lowering the levels of trace elements in this study were the duration of exposures to pesticide and fertilizer and the PPE practices used by the farmers. The results showed that the levels of trace elements in the nails and hair of farmers who use pesticides and fertilizers were low. This result may have been caused by the accumulation of elements, such as heavy metals from environmental pollution due to the use of pesticides and fertilizers; these heavy metals can interact with and reduce the levels of trace elements in the body. However, there are also trace elements that were at high levels in the body. In addition to the duration of exposure and PPE practices used, other factors such as gender, age, smoking status, dietary habits and health status did not seem to have a strong influence on trace element levels in the nails and hair of the farmers. This study also showed that the duration of the exposures did not play an important role in lowering the levels of trace elements. Instead, the use of PPE practice was more important in determining the rate of exposure to pesticides and fertilizers, which in turn could lower the levels of trace elements in the body. Therefore, the employment and safety aspects of handling pesticides and fertilizers must be properly considered in order to minimize the exposure to these materials.

\section{Acknowledgements}

This research was supported by Universiti Kebangsaan Malaysia (KOMUNITI-2012-013). Special thanks to all colleagues who provide insight and expertise that greatly assisted this study. Lastly, deepest gratitude to all farmers, staff and students for willing to help and participate in this study.

\section{References}

Adair, B. M., Hudgens, E. E., Schmitt, M. T., Calderon, R. L., \& Thomas, D. J. (2006). Total arsenic concentration in toenails quantified by two techniques provides a useful biomarker of chronic arsenic exposure in drinking water. Environmental Research, 101(2), 213-220. https://doi.org/10.1016/j.envres. 2005.08.004

Atreya, K. (2007). Pesticide use knowledge and practices: A gender differences in Nepal. Environmental Research, 104, 305-311. https://doi.org/10.1016/j.envres.2007.01.001

Bergomi, M., Rovesti, S., Vinceti, M., Vivoli, R., Caselgrandi, E., \& Vivoli, G. (1997). Zinc and copper status and blood pressure. Journal of Trace Elements in Medicine and Biology, 11, 166-169. https://doi.org/ 10.1016/S0946-672X(97)80047-8

Centers for Disease Control and Prevention (CDC). (2006). The health consequences of smoking: What it means to you. The Surgeon General's Report (pp. 1-36).

Chojnacka, K., Zielinska, A., Michalak, I., \& Gorecki, H. (2010). Inter-relationship between elements in human hair: The effect of gender. Ecotoxicology and Environmental Safety, 73, 2022-2028. https://doi.org/10.1016/ j.ecoenv.2010.09.004

Clark, N. A., Teschke, K., Rideout, K., \& Copes, R. (2007). Trace element levels in adults from the West Cost of Canada and association with age, gender, diet, activities and levels of others trace elements. Chemosphere, 70, 155-164. https://doi.org/10.1016/j.ecoenv.2010.09.004

Dosemeci, M., Alvanja, M. C. R., Rowland, A. S., Mage, D., Zahm, S. H., Rothman, N., ... Blair, A. (2002). A quantitative approach for estimating exposure to pesticides in agricultural health study. Annals of Occupational Hygiene, 46(2), 245-260. 
Fleming, L. E., Gomez-Martin, W. O., Zheng, D. E., Ma, F., \& Lee, D. (2003). National health interview survey mortality among US farmers and pesticide applicators. American Journal of Industrial Medicine, 43, 227-33. https://doi.org/10.1002/ajim.10162

Ghadirian, P., Maisonneuve, P., Perret, C., Kennedy, G., Boyle, P., Krewski, D., \& Lacroix, A. (2000). A case-control study of toenail selenium and cancer of the breast, colon and prostate. Cancer Detection and Prevention, 24(4), 305-313.

Ghazali, A. R., Abdul Razak, N. E., Othman, M. S., Othman, H., Ishak, I., Lubis, S. H., \& Abdullah, R. (2012). Study of heavy metal levels among farmers of Muda Agricultural Development Authority, Malaysia. Journal of Environmental and Public Health, 2012, 1-4. http://dx.doi.org/10.1155/2012/758349

Griffith, H. W. (2000). Mineral supplement and vitamins. The essential guide. Arizona: Fisher Book.

Hamilton, I. M., Gilmore, W. S., \& Strain, J. J. (2000). Marginal copper deficiency and atherosclerosis. Biological Trace Element Research, 78, 179-189. https:/doi.org/10.1385/BTER:78:1-3:179

Ismarulyusda, I., Jamaludin, M., Khairul, O., Zaleha M. I., Zakiah, I., Fairulnizal, M., \& Osman, A. (2009). Serum selenium status among populations in Hulu Langat District, Selangor, Malaysia. Sains Malaysiana, 38(4), 473-481.

Ismarulyusda, I., Zaleha, M. I., Jamaludin, M., Khairul, O., Iskandar Zulkarnain, A., Khalid, B. A. K., \& Osman, A. (2005). Micronutrient levels among Aborigines in Pahang \& Perak. Jurnal Kesihatan Masyarakat, 11(2), 21-25.

Jeejeebhoy, K. N. (1994). Zinc and chromium in parenteral nutrition. Bulletin of the New York Academy of Medicine, 60, 118-124. https://doi.org/10.1053/j.gastro.2009.08.014

Jeyaratnam, J. (1990). Acute pesticide poisoning: A major global health problems. World Health Statistics Quarterly, 43, 139-144.

Longnecker, M. P., Stampfer, M. J., Morris, J. S., Spate, V., Baskett, C., Mason, M., \& Willett, W. C. (1993). A 1-y Trial of the effect of high-selenium bread on selenium concentrations in blood and toenails. The American Journal of Clinical Nutrition, 57(3), 408-413.

Mann, J., \& Truswell, A. S. (2002). Essential of human nutrition (2nd ed.). New York: Oxford University Press.

Mehra, R., \& Jenuja, M. (2004). Biological monitoring of lead and cadmium in human hair and nail and their correlations with biopsy materials, age and exposure. Indian Journal of Biochemistry and Biophysics, 41(1), 53-56. Retrieved from http://hdl.handle.net/123456789/3636

Mortada, W. I., Sobh, M. A., \& El-Defrawy, M. M. (2004). The exposure of cadmium, lead and mercury from smoking and its impact on renal integrity. Medical Science Monitor, 10(3), 112-116.

Moukarzel, A. (2009). Chromium in parenteral nutrition: Too little or too much? Gastroenterology, 137, S18-S28. https://doi.org/10.1053/j.gastro.2009.08.048

Nordin, R., Araki, S., Sato, H., Yokoyama, K., Wan Muda, W. A. M., \& Win Kyi, D. (2001). Gender difference in safe and unsafe practice of pesticide handling in tobacco farmers of Malaysia. Malaysian Journal of Medical Sciences, 8(1), 1-10.

Nurfariha, F., Ismarulyusda, I., Syarif, H. L., Nooraisyah, M., Hidayatul Fathi, O., Nihayah, M., ... Mohamad Roff, M. (2014). Faktor yang mempengaruhi paras kromium dalam kalangan petani di Daerah Bachok dan Pasir Puteh, Kelantan. Jurnal Sains Kesihatan Malaysia, 12(2), 27-31. https://doi.org/10.17576/ JSKM-2015-1202-04

Rayman, M. P. (2000). Review: The importance of Selenium to Human Health. Lancet, 356(9225), $233-241$. https://doi.org/10.1016/S0140-6736(00)02490-9

Rodrigues, J. L., Batista, B. L., Nunes, J. A., Passos, C. J. S., \& Barbosa, J. R. F. (2008). Evaluation of use of human hair for biomonitoring the deficiency of essential and exposure to toxic elements. Science of the Total Environment, 405, 370-376. https://doi.org/10.1016/j.scitotenv.2008.06.002

Rodushkin, I., \& Axelsson, M. D. (2000). Application of double focusing sector field ICP-MS for multi-elemental characterization of human hairs and nails. Part I. Analytical methodology. Science of the Total Environment, 250, 83-100. https://doi.org/10.1016/S0048-9697(00)00369-7

Ryabukhin, Y. S. (1978). Activation analysis of hair as an indicator of contamination of man by environmental trace element pollutants. IAEA Report IAEA/RL/50, Vienna. 
Shomar, B. H. (2006). Trace elements in major solid-pesticides used in the Gaza Strip. Chemosphere, 65, 898-905. https://doi.org/10.1016/j.chemosphere.2006.03.004

Slotnick, M. J., \& Nriagu, J. O. (2006). Validity of human nails as a biomarker of arsenic and selenium exposure: A review. Environmental Research, 102, 125-39. https://doi.org/10.1016/j.envres.2005.12.001

Sukumar, A. (2006). Human nails as a biomarker of element exposure. Reviews of Environmental Contamination and Toxicology, 185, 141-177. https://doi.org/10.1007/0-387-30638-2_5

Sukumar, A., \& Subramanian, R. (1992). Elements in hair and nails of urban residents of New Delhi: CHD, hypertensive and diabetic cases. Biological Trace Element Research, 34, 89-98. https://doi.org/10.1007/ BF02783901

Suzana, S., Earland, J., \& Suriah, A. R. (2000). Validation of a Dietary History Questionnaires against a 7-D Weighed Record for estimating nutrient intake among rural elderly Malay. Malaysian Journal of Nutrition, 6, 33-34.

Wąsowicz, W., Gromadzińska, J., \& Rydzyński, R. (2001). Blood Concentration of Essential Trace Elements and Heavy Metals in Workers Exposed to Lead And Cadmium. International Journal of Occupational Medicine and Environmental Health, 14(3), 223-229.

Watts, D. L. (1989). The nutritional relationship of copper. Journal of Orthomolecular Medicine, 4, 99-105.

Watts, D. L. (1990). The nutritional relationship of manganese. Journal of Orthomolecular Medicine, 5(4), 211-222.

Zariyantey, A. H., Zaliha, H., Syarif, H. L., Nihayah, M., Ismarulyusda, I., Hidayatul Fathi, O., \& Jamil, R. (2014). Adoption of the Mobile Health Screening Programme for farming communities: A study among pesticide-exposed farmers from North East of Peninsular Malaysia. Jurnal Sains Kesihatan Malaysia, 12(2), 63-69. https://doi.org/10.17576/JSKM-2015-1202-09

\section{Copyrights}

Copyright for this article is retained by the author(s), with first publication rights granted to the journal.

This is an open-access article distributed under the terms and conditions of the Creative Commons Attribution license (http://creativecommons.org/licenses/by/4.0/). 